\title{
The society's perceptions on the use of fintech services in sharia financial institutions
}

\author{
Rinrin Yuspita, Silviana Pebruary*, Aulia Zahra Husnil Kamala, \\ Universitas Islam Nahdlatul Ulama Jepara, Jepara, Indonesia \\ *Corresponding author: silvy@unisnu.ac.id
}

Keywords:

Perception, Fintech, Sharia

Financial Institution

\section{Article History}

Received : 30 July 2019

Accepted : 5 August 2019

Published: 9 August 2019

DOI:

10.20885/JEKI.vol5.iss2.art6

JEL:

E44, G21, O21, 014, Z12

\begin{abstract}
In the development of industrial revolution 4.0, sharia financial institutions keep improving their product innovation through the use of financial technology (fintech). Through development and innovation, society is expected to keep up to date with the current financial services. This research aims to investigate how the interest in using sharia services affected by several factors, such as convenience, benefits, attitude, and suitability. This research uses a descriptive quantitative method through multi-linear regression analysis. The population of the research is Jepara people who use sharia fintech services. The sample is selected through incidental sampling. The research findings reveal that convenience, attitude, and benefit affect sharia fintech users' perceptions of the use of services provided by sharia financial institutions. Meanwhile, trust and suitability do not affect users' perceptions.
\end{abstract}

\section{Introduction}

The economic activity of a country is related to the flow of money and payments in which financial institutions play a crucial role in this activity and are considered as the core of a business. The existence of the financial institution is needed to support economic development in Indonesia. As financial institutions progress, economic growth will be faster. Indonesia is a country that uses a dual financial system, those are conventional and sharia. In this globalization era, both institutions are required to show better performance and services.

The number of conventional and sharia financial institutions (bank and non-bank) as of December 2018 was 3.084 units, where the number of banking companies in Indonesia as of December 2018 was 1,903 units consisting of 201 Islamic banking and 1,702 conventional banking (OJK). Non-Bank Financial Industry (IKNB) as of December 2018 reached 1,181 units consisting of 1,093 conventional IKNB units and 88 IKNB Syariah units (OJK, 2019). The increase in the number of sharia financial institutions can increase competition among financial institutions in Indonesia. This leads to a condition where the financial institution should provide additional values to its customers by providing the services they need.

According to the Digital Marketing Research Institute (e-marketer), it is estimated that in 2018 the number of active smartphone users in Indonesia is more than 100 million people. With such a large number, Indonesia will become the fourth-largest smartphone user in the world after China, India, and America (Ministry of Communication and Information Technology [MOCIT], 2015). While the internet user population of the country reaches 123 million people in 2018. It means Indonesia ranks 6th as the largest internet user in the world. With the population of Jepara Regency in 2017 as many as $1,223,198$ people, $60.43 \%$ of the population in 2018 will have used cellphones (MOCIT, 2014).

The growth of the number of internet users and the use of cellphones can be used as a consideration by financial institutions in developing their services tailored to society's development (Kurniawan, 2013). Currently, cellphones are not only used as a means of communication but also to perform online financial services, such as bill payments, account transfer, person-to-person transfer, proximity payments at the point of sale, long-distance payments to buy goods and services, and other types of services such as location-based, cellular marketing, tickets, discounts or coupons (Oliveira, Thomas, Baptista, \& Campos, 2016).

One of the services that has been developed by the banking sector is an online banking system. Online banking is a banking transaction service that can be performed by customers either from home, place of business or in other locations that are not in the real bank location (branch office) by using communication media such as computers, cellular phones, and landlines. Forms of online banking services are Automatic Teller Machine (ATM) and electronic banking (e-banking) (Irmadhani, 2012). Bank Indonesia divides e-banking services into 4 categories, namely internet banking, mobile banking, phone banking, and Short Messege Service (SMS) banking. 
E-banking is a type of flexible service since it can be used to help customers do financial transactions anywhere and anytime. A wide opportunity to enter the market for this type of mobile banking service is a challenge for the banking industry to explore the factors that affect customers prefer to use e-banking (Kurniawan, 2013). In line with the objectives of sharia financial institutions, they are expected to serve optimally in order to maintain the reputation and the independence of the institution. Services follow the digitalization era, namely financial technology (fintech) as a service system to facilitate customers and institutions.

In this study, the factors that influence the community preference of using fintech services in sharia financial institutions will be observed, where the variables to be observed are based on the variables in TAM. Technology Acceptance Model (TAM), was first introduced by Davis in 1989. Technology Acceptance Model (TAM). TAM was specifically created for modeling the adoption of information system users.

According to Davis (1989), the main purpose of TAM is to establish a basis for tracking the influence of external factors on trust, attitudes (personalization), and goals of computer users. TAM considers that the two main behavioral variables in adopting information systems are the usefulness and ease of use. The benefit user perceptions are defined as the rate at which a person believes that using a particular system can improve his performance, and the ease of using internet banking is defined as the level at which someone believes that using a system does not require much effort. The ease of using internet banking also influences user perceptions of the benefits which can also be interpreted that if people feel that a system is easy to use, the system is useful for them (Wijayanti, 2011).

\section{Research Methods}

The methodology used in this research is quantitative descriptive with the population of Jepara people who had savings in sharia financial institutions. The sampling technique was incidental sampling that is based on coincidence in which anyone who accidentally or incidentally meets with the researcher can be used as a sample if he is considered suitable as a data source. In collecting data using questionnaires, samples obtained were 193 respondents. the independent variables used in this study are Perceived Ease, Perceived Benefit, Trust, Attitude, and Conformity.

Perceived Ease (PE), the belief that the system is useful at any time and facilitates transactions, services can be understood, speed of access. PE indicator consists of easiness to perform, reliability and the easiness to install the application of e-banking services. (Wijaya, 2006)

Perceived Benefit (PB), the degree at which someone believes that using a particular system can improve its performance, effective, the linkage. In short, the extent to which benefits can be felt by users in using technology systems. PB consists of flexibility (time \& place), help customers in doing their tasks, and faster transaction process.

Trust (TR) can be interpreted as a willingness to be placed in an easy-to-feel situation based on future expectations (Mayer, et al., 1995). The use of mobile banking by customers can be done if the customer has trust on the bank (Gu, et al., 2009). The impact of trust in services is the willingness of customers to use these services, on the contrary, if there is a lack of trust in services, there will be a lack of interest of customers in using the services (Chandra, et al., 2010). Trust has a significant negative relationship with the intention of using longdistance mobile payments (Slade et al., 2015). The indicators of perceived trust are bank security system when using e-banking service, bank secrecy system, and customers trust on innovation.

Attitude (AT), attitude is developed over time when someone gets to experience. Attitudes are considered as multidimensional constructs consisting of cognitive, emotional, and conative dimensions or behavior. The feeling of 'profitable' or 'unprofitable' towards certain behaviors reflects an attitude (Fishbein, 1963), where it shows that attitudes are developed in a time when someone gets to experience. However, different theoretical models (TAM, TRA, and TPB) have found that attitude is an important prerequisite in the intention to develop a particular behavior (Ajzen, 1980). A study revealed that the attitude of Fintech software users had a positive effect on the interest in using the software (Suyanto \& Kurniawan, 2019).

Attitudes are considered as multidimensional constructs, which consist of dimensions of cognitive, emotional, and conative or behavior (Fishbein \& Ajzen, 1975). Individual knowledge about a product or service (experience, trust and opinion) is driven by the cognitive component, while individual preferences about the given object (feelings, emotions, and evaluations) and ultimately driven by emotional components, and behavioral intentions (purchase intention, purchase response, and rejection responses) are conative components (Alonso, 2004).

Conformity (CO), characteristics such as users who reflect social image and requirements, personal values, lifestyle, beliefs, and experiences. Conformity in m-banking services has characteristics such as; it reflects social image and requirements, personal values, lifestyle, beliefs and experiences (Rogers, 2003). Conformity has a significant direct or indirect effect on the preference to adopt and recommend mobile payment technology 
(Oliveira et al., 2016). The indicators of the conformity variable that researchers consider are only components of lifestyle and social image

While the dependent variable "Interest in using fintech" (FUI), a person's behavior depends on one's attitude about behavior and subjective norms. When someone intends to do a particular behavior, it is possible that he will do that behavior.

This study used a quantitative method with multiple linear regression analysis techniques. Multiple linear regressions are explained through several stages of testing (BLUE ESTIMATE) including validity, reliability, normality and classic assumptions for the feasibility study model which then tested the hypothesis using partial and simultaneous tests with the following regression equation:

$F U I=\beta_{1} P E+\beta_{2} P B+\beta_{3} T R+\beta_{4} A T+\beta_{5} C O$

\section{Result and Discussion}

The results of sample collection obtained 193 respondents consisting of $69.43 \%$ men and $30 \%$ women. The age of respondents are 25-30 years $(27.46 \%)$, 31-35 years $(19.69 \%), 36-40$ years $(44.56 \%)$, and above 40 years $(8.29 \%)$. Meanwhile, respondents' occupation status are students (27.98\%), self-employed (40.93\%), and private employees (31.09\%). Data processing of this study shows the determination coefficient of $66 \%$ of the regression model. Testing of data validity shows valid data with the average of $r_{\text {obtained }}$ is more than $r_{\text {table }}$ and the reliable obtained $r_{\text {table }}$ (one-tailed) value $=0.1716$ which is higher than $r_{\text {obtained }}$ value of each variable. Based on this, it can be concluded that the data is valid. While for reliability, it can be seen from the value of Cronbach's Alpha $=0.948$ $>0.6$, thus the variables are reliable.

This test is carried out simultaneously by using the F-test or using the t-test on the dependent variable (Interest Using Fintech). So, it will be found whether the independent variables affect the dependent variables. Regression model of this study resulted in the coefficient of determination of 0.443 . Then the dependent variable can be explained if the independent variable is $44.3 \%$, and the rest is explained if other variables are outside the model. The following are the results of the regression equation:

$F U I=0.190 P E+0.284 P B+0.016 T R+0.231 A T+0.126 C O$

Table 2. Regression equations estimation results

\begin{tabular}{lccccc}
\hline Model & \multicolumn{2}{c}{ Coefficients unstandardized } & standardized Coefficients & $\mathrm{t}$ & Sig. \\
\cline { 2 - 6 } & $\mathrm{B}$ & Std. Error & Beta & & 0.640 \\
(Constant) & 1.804 & 2.818 & & 2.477 & 0.523 \\
PE & 0.133 & 0.054 & 0.190 & 4.029 & $* 0.000$ \\
PB & 0.285 & 0.071 & 0.284 & 0.217 & 0.829 \\
TR & 0.018 & 0.084 & 0.016 & 3.421 & $* 0.001$ \\
AT & 0.273 & 0.080 & 0.231 & 1.729 & 0.085 \\
CO & 0.388 & 0.225 & 0.126 & & \\
\hline
\end{tabular}

a. Dependent Variable: FUI

Based on partial testing results between Perceived Ease and Interest using fintech, it is found that sig.t is $0.014<0.05$ (Table.2) which means that Ho is rejected and Ha is accepted. Thus, it can be concluded that there is a significant effect between Perceived Ease and Interest using fintech. The coefficient value of perceived ease is 0.190 (Table.2), then the interest in fintech services is 0.190 or $19 \%$ if the perception of public convenience increases by one unit.

Accordingly, there is a significant influence between Perceived Benefit and Interest in using e-banking services, it shows that the higher the perceived benefit, the higher the interest in using e-banking services in Jepara. The use of the services depends on the ease of access or ease of service features. In choosing a sharia financial institution that will be used as a place to have saving or financing, community considers a sharia financial institution that has fintech services which are easily accessible at any time and the features of the services can be used in everyday life. The results are in line with Liébana-Cabanillas et al. (2014), Kurniawan (2013), Amalia (2018), and Gunawan (2014) who stated that perceived ease has a significant effect on the interest.

From Table 2, it shows that there is a significant influence between the Perceived Benefit and Interest in using e-banking services. Coefficient value of perceived benefit is 0.284 and that of the interest in fintech services is 0.284 or $28,4 \% \%$. The results show that the higher the perceived benefit, the higher the interest in using ebanking services in Jepara. 
The benefits of fintech services felt by users are the reason for using fintech services in everyday life. For example, for users who are familiar with online shopping, they will feel the benefits in using fintech services in sharia financial institutions. Community perceived benefit viewed from the usefulness of each service is to be effective and efficient in conducting transactions. The results of this study are in line with de Kerviler, Demoulin, \& Zidda (2016), Kurniawan (2013), Amalia (2018), and Gunawan (2014) who stated that perceived benefits significantly influence interest.

From Table 2, it shows that the relationship of Trust and Interest using fintech has sig.t is $0.829>0.05$ which means that Ho is accepted and $\mathrm{Ha}$ is rejected. Coefficient value of Trust is 0.016 (Table.2) and that of Interest in fintech services is 0.016 . Thus, it can be concluded that there is no significant influence between trust on the interest in using e-banking services. The results show that trust in fintech or digital services is not dominant as a reason for making decisions using e-banking fintech services. This study has the same results as the research conducted by Slade et al., (2015). Trust is not a factor for customers to use fintech services in Islamic financial institutions. Therefore, people's perceptions in using fintech services are not influenced by trust. It can be seen from Table 2 that the coefficient value of trust is the smallest value, only $1.6 \%$.

Based on the result of testing between Attitude and Interest using fintech, Table 2 shows that sig.t is 0.001 which means that there is a significant influence between attitudes and interest in using e-banking services. From Table 2, coefficient value of attitude is 0.231 and that of interest in fintech services is 0.231 . The results of the study show that the attitude of the user after getting experience from other people, seeing other people using the service will attract others to use e-banking services in Jepara.

Community Interest Users of fintech Islamic financial services are influenced by information obtained from other users, the experiences of other users that make them confident to use the fintech services. In addition, the attitude of the public who are curious about the technology of lambaga sharia financial services at this time which is a trend in making transactions makes customers interested in using the fintech services of the Islamic financial institutions. The results of this study support other research by Liébana-Cabanillas, Sánchez-Fernández, \& Muñoz-Leiva, (2014), Suyanto \& Kurniawan (2019), Kurniawan (2013), and Lorenzo et al. (2011) that attitude will influence people's intention according to their beliefs.

Based on the results of testing between variable Conformity and Interest using fintech, it is found that sig.t is $0.085>0.05$ (Table 2) which means that Ho is accepted and Ha is rejected. Thus, it can be concluded that there is no significant influence between Conformity and Interest using fintech. Moreover, there is no significant influence between the conformity of the interest in using e-banking services. With a coefficient value of 0.126 (Table 2), interest in using fintech is 0.126 . However suitability has no influence on the change in percentage of interest in using fintech services.

According to users, the suitability of fintech services with user needs is not a factor that makes people interested or interested in using fintech services. Where users feel the convenience, benefits of fintech services, the decision to use fintech services will be even greater. The Jepara community in using fintech does not see the conformity of its services which can be seen from the results in Table 2. The coefficient value of the perceived benefit is more dominant to influence interest in using digital services. However, in a study conducted by Mallat, et al. (2009), it shows that compatibility is a determinant of the use of virtual services.

From the data of the test results of variable Perceived Ease, variable Perceived Benefit, variable Trust, variable Attitude, and variable Conformity towards variable Interest using fintech, it is found that significant $F$ is 0.0000 which means that there are significant influences between variable Perceived Ease, variable Perceived Benefit, variable Trust, variable Attitude, and variable Conformity that affect Interest using fintech. Simultaneously, these independent variables will affect one's perceptions in using fintech services because each element of the variable is interrelated and if combined will affect more someone's interest in using digital services. Also, from the coefficient result, something that is more dominant is based on the perception of service benefits of 0.284 in which the people use fintech based on the benefits obtained from the use of theses services.

\section{Conclusion}

In the development of era 4.0 today, it requires innovation from sharia financial institutions to compete in the financial market. Innovation is realized by providing online services for banking members, without neglecting the fact that not all members use technology-based financial services (fintech). To find out whether the market shares are right or not, several factors influence community perception on fintech of sharia financial institutions which are convenience, benefits, and attitudes, while trust and conformity do not influence the perception of fintech users. Overall, perceived benefit is a major factor in using fintech. The limitation of this study is that the scope of the research is only the fintech m-banking service and the sample taken is only the perception of Jepara community. For further research, it is expected to use a wider coverage of research sample. The results of this study recommend sharia financial institutions to improve service innovations that provide convenience, benefits for customers which 
ultimately will attract the interest of prospective customers to become customers of sharia financial institutions. In addition to that, enhancing security from the use of fintech could make customers loyal to sharia financial institutions.

\section{References}

Ajzen, I. \&. (1980). Understanding attitudes and predicting social behavior. London: Prentice Hall International.

Alonso, J. \&. (2004). Comportamiento del Consumidor. Decisiones y Estrategias de Marketing (5th ed.). Madrid: ESIC.

Amalia, S. N. A. (2018). Faktor-faktor yang mempengaruhi minat individu terhadap financial technology (fintech) syariah (paytren) sebagai salah satu alat transaksi pembayaran pendekatan Technology Acceptance Model (TAM) dan Theory of Planned Behavior (TPB). Iqtishaduna, 8 (1), 57-73. Retrieved From http://Journal.Uinmataram.Ac.Id/Index.Php/Iqtishaduna/Article/View/687

Bank Indonesia. (2013). Financial Technologies (Fintech). Retrieve form https://www.bi.go.id/id/sistempembayaran/fintech/contents/default.aspx

Chandra, S., Srivastava, S. C., \&Theng, Y.-L. (2010). Evaluating the role of trust in consumer adoption of mobile payment systems: an empirical analysis. Communications of the Association for Information systems, 27, 561-588. Retrieved From Http://Aisel.Aisnet.Org/Cais/Vol27/Iss1/29

Davis, F. D. (1989). Perceived usefulness, perceived ease of use, and user acceptance of information technology. MIS Quarterly, 13 (3), 319. https://doi.org/10.2307/249008

De Kerviler, G., Demoulin, N. T. \& Zidda, P. (2016). Adoption of in-store mobile payment: are perceived risk and convenience the only drivers? Journal Of Retailing and Consumer Services, 31, 334-344. https://doi.org/10.1016/j.jretconser.2016.04.011

Fishbein, M. (1963). An investigation of the relationships between beliefs about an object and the attitude toward that object. Human Relations, 16, 233-240.

Fishbein, M., \& Ajzen, I. (1975). Belief, attitude, intetion, an behavior: An introduction to theory and research. Addison-Wesley: Reading, MA.

Gu, J.C., Lee, S.C., \& Suh, Y. H. (2009). Determinants of behavioral intention to mobile banking. Expert Systems with Applications, 36 (9), 11605-11616. https://doi.org/10.1016/j.eswa.2009.03.024

Gunawan, A. (2014). Aplikasi technology acceptance model pada minat nasabah untuk menggunakan internet banking. Nominal, 3 (2). Https://doi.org/10.21831/nominal.v3i2.2695

Helda. (2018). Bukan cuma layanan pinjam uang, ini cakupan perusahaan fintech. Moneysmart. Retrieved form https://www.moneysmart.id/fintech-di-indonesia-ini-contoh-kategori-financial-technology/

Irmadhani. (2012). Pengaruh persepsi kebermanfaatan, persepsi kemudahan penggunaan dan computer self efficacy, terhadap penggunaan online banking pada mahasiswa S1 fakultas ekonomi Universitas Negeri Yogyakarta. Kajian Pendidikan Akuntansi Indonesi, 1 (3). Retrieved From https:/journal.uny.ac.id/index.php/jkpai/article/view/882

Kang, J. (2018). Mobile payment in fintech environment: Trends, security challenges, and services. HumanCentric Computing and Information Sciences, 8 (1), 32.

https://doi.org/10.1186/s13673-018-0155-4

Kurniawan, D. (2013). Analisis Penerimaan Nasabah Terhadap Layanan Mobile Banking dengan Menggunakan Pendekatan Technology Acceptance Model dan Theory of Reasoned Action. Jurnal Startegi Pemasaran, 1 (1). Retrieved from http://publication.petra.ac.id/index.php/manajemen-pemasaran/article/view/67

Liébana-Cabanillas, F., Sánchez-Fernández, J., \& Muñoz-Leiva, F. (2014). Antecedents of the adoption of the new mobile payment systems: The moderating effect of age. Computers in Human Behavior, 35, 464-478. https://doi.org/10.1016/j.chb.2014.03.022

Majid, M. (2014). Mengenal fintech inovasi sistem keuangan di era digital. Retrieved from https://www.maxmanroe.com/mengenal-fintech-inovasi-sistem-keuangan-di-era-digital.html

Mayer, R. C., Davis, J. H., \& Schoorman, F. D. (1995). An integrative model of organizational trust. The Academy 
of Management Review, 20 (3), 709. https://doi.org/10.2307/258792

Ministry of Communication and Information. (2014). Pengguna internet Indonesia nomor enam dunia. Retrieved from https://kominfo.go.id/content/detail/4286/pengguna-internet-indonesia-nomor-enam-dunia/0/sorotan_media

Ministry of Communication and Information. (2015). Indonesia raksasa teknologi digital Asia. Retrieved form ttps://kominfo.go.id/content/detail/6095/indonesia-raksasa-teknologi-digital-asia/0/sorotan_media

Financial Service Authority. (2019). Statistics IKNB. Retreive form https://www.ojk.go.id/id/kanal/iknb/data-danstatistik/statistik-iknb/pages/statistik-iknb-periode-desember-2018---revisi.aspx

Oliveira, T., Thomas, M., Baptista, G., \& Campos, F. (2016). Mobile payment: Understanding the determinants of customer adoption and intention to recommend the technology. Computers in Human Behavior, 61, 404-414. https://doi.org/10.1016/j.chb.2016.03.030

Rogers, E. M. (2003). Diffusion of inovations. New York: NY: Free Press.

Slade, E. L., Dwivedi, Y. K., Piercy, N. C., \& Williams, M. D. (2015). Modeling consumers' intentions adoption of remote mobile payments in the united kingdom: Extending UTAUT with innovativeness, risk, and trust. Psychology \& Marketing, 32 (8), 860-873.

https://doi.org/10.1002/mar.20823

Stewart, H., \& Jürjens, J. (2018). Data security and consumer trust in fintech innovation in Germany. Information and Computer Security, 26 (1), 109-128. https://doi.org/10.1108/ICS-06-2017-0039

Suyanto, S., \& Kurniawan, T. A. (2019). Faktor yang mempengaruhi tingkat kepercayaan penggunaan fintech pada UMKM dengan menggunakan technology acceptance model (TAM). Akmenika, 16 (1). Retrieved from https://journal.upy.ac.id/index.php/akmenika/article/view/166

Wijayanti, R. (2011). Analisis technology acceptance model (TAM) terhadap faktor-faktor yang mempengaruhi penerimaan nasabah terhadap layanan internet banking (studi empiris terhadap nasabah bank di Depok). Proceeding PESAT (Psychology, Economics, Literature, Architecture and Civil), Universitas Gunadarma, 4, 121-127. Retrieved from https://www.researchgate.net/publication/264888175

Wijaya, S. W. (2006). Theoretical study of the technology acceptance model for model approach to determine willingness strategies encourage users in using information and communication technology. Proceedings of the Conference on Information Systems. 